\title{
STRATEGY AND POLICY STATEMENTS ON GREEN ICT: AN ISLAMIC PERSPECTIVE
}

\author{
SHIHAB A. HAMEED \\ Electrical and Computer Engineering Department, \\ International Islamic University Malaysia, \\ Jalan Gombak, 53100 Kuala Lumpur, Malaysia. \\ shihab@iium.edu.my
}

\begin{abstract}
In this information and knowledge era; ICT development and industry are growing very fast and associated with huge procurement force. Today, the global society is facing serious challenges in improving environmental performance, particularly with climate change, global warming, and resource management. ICT industry is widely contributing to the global economy associating with innovation, invention and rapid development of almost all the aspect of human life. On other hand; ICT industry is responsible for global $\mathrm{CO}_{2}$ emissions. Global environmental problems are affecting directly many countries' energy and industrial policies. The rapid increasing of ICT usage means more energy consumption and more environmental problems and the estimated ICT consumption of energy will be about $15 \%$ of the total consumption worldwide in 2020. Therefore, many countries are establishing Green ICT policies which increase energy efficiency due to correspondence climate change. Therefore, governments especially in developing and Islamic countries need to adopt new strategic policies for efficient energy use in ICT. This study presents the current environmental problems related to green ICT and the efforts to solve it. Several studies have warning from the current energy consumption paradigm, based on newly changed ICT practices. This study provides guidelines for decision makers and ICT professionals to enhance their work toward green ICT and eliminating environmental problems. Islamic viewpoint on environment and its protection is considered since it offers comprehensive, stable, and fair viewpoint that is based on main Islamic sources; Qur'an and Sunnah. Hundreds of Qur'anic verses and prophet Hadiths clarify (directly or indirectly) the right manner in dealing and protection of environment resources. This paper proposes a framework for strategy and policy statements of green ICT based on Islamic perspective to serve the world especially developing and Islamic countries.
\end{abstract}

ABSTRAK: Di era informasi dan komunikasi teknologi (ICT) kini, pembangunan ICT dan industri berkembang begitu pesat dan dikaitkan dengan daya membeli yang tinggi. Hari ini, masyarakat dunia menghadapi cabaran dalam meningkatkan prestasi persekitaran, terutamanya dengan perubahan cuaca, pemanasan global, dan pengurusan sumber. Industri ICT merupakan penyumbang sebahagian besar daripada ekonomi global yang berkaitan dengan inovasi, reka cipta dan perkembangan pesat hampir semua aspek manusia. Di sebaliknya pula, industri ICT bertanggung jawab terhadap pelepasan $\mathrm{CO} 2$ global. Masalah persekitaran global secara langsung mempengaruhi polisi tenaga dan industri banyak negara. Pembangunan pesat ICT menyebabkan meningkatnya penggunaan tenaga dan pertambahan masalah persekitaran. Penggunaan tenaga oleh ICT dianggarkan mencapai jumlah $15 \%$ daripada jumlah penggunaannya di seluruh dunia pada tahun 2020. Oleh itu, banyak negara yang membentuk polisi ICT Hijau supaya kecekapan tenaga dapat ditingkatkan seiring dengan perubahan cuaca. Kerajaan terutamanya di negara-negara membangun dan negara Islam lain haruslah mengamalkan polisi baru yang wajar agar tenaga digunakan secara efisien di bidang ICT. Kajian ini 
membentangkan masalah persekitaran yang kini berkaitan dengan menhijaukan ICT dan usaha-usaha untuk meyelesaikannya. Beberapa kajian berbentuk peringatan berasaskan paradigma penggunaan tenaga terkini, berdasarkan kepada amalan terbaru ICT yang dipinda. Kajian memberikan garis panduan kepada pembuat-pembuat keputusan dan para professional ICT untuk mempertingkatkan usaha mereka ke arah ICT hijau dan menyelesaikan masalah alam sekitar. Pandangan Islam terhadap alam sekitar dan usaha melindunginya dipertimbangkan, memandangkan ianya memberi pendapat yang menyeluruh, stabil dan adil berdasarkan sumber-sumber Islam iaitu Quran dan Sunnah. Banyak ayat-ayat Al-Quran dan hadis-hadis memperjelaskan (secara langsung atau tidak langsung) cara yang betul dalam menangani dan melindungi sumber alam sekitar. Kertas ini juga mencadangkan rangka kerja untuk pernyataan strategi dan polisi untuk menhijaukan ICT berdasarkan perspektif Islam dalam berkhidmat kepada dunia, terutamanya di negara-negara membangun dan negara-negara Islam.

KEYWORDS: green ICT; ICT professionals; strategy statement; environment problem; Islamic perspective

\section{INTRODUCTION}

The rapid development in electrical, electronics information and communication technology leads to the huge production of such products. The strong procurement power for such products is mainly because of the big number of announcements in different media as well as reduction of products' prices. This leads to the unwise behavior of customers in buying products regardless of their actual needs. The result is more consumption of energy in production and operating ICT product, which lead to significant problems related to environment. Climate change, green house gas - GHG emission, and global warming are the key challenges facing global society since quarter of century. Leaders, governmental and non-governmental organizations, universities and institutes, scientists, research centers and individual researchers work through different activities to face such challenges. These activities include: organizing summits, conferences, seminars, workshops, research projects, and other activities. They work toward finding efficient and effective solutions for better utilization and management for resources, improving environmental performance, and eliminate global warming. Computers, computer-based applications, information technology, and communications become essential part and have tremendous effects on human life (directly or indirectly). The information and communication technology (ICT) industry has a significant role and contribution to the global economy; but on the other hand ICT is responsible for $2-3 \%$ of the global carbon footprint [1].

ICT growth and usage increasing rapidly in the world; include many developing and Muslim countries (Asia and Africa). The emerging economy and technological advances in many of the growing developing and Islamic countries (Malaysia, Turkey, some Arabian Gulf countries (Saudi Arabia and UAE), etc) as well as the two super population countries China and India (about 2.5 billions) leads to a rapidly increasing of global access of ICT services. This will bring more environmental problems due to the sudden increment on the power request from the ICT systems [2].

The increasing usage of ICT equipments and the highly dependence on ICT applications in almost all aspects of life; implies facing ICT harmful affect on environment and other social aspects. Sustainable existence of Human and other creatures on Earth requires that our future ICT technologies must be inherently sustainable both by nature 
and in usage [3]; but facing the main challenges related to global warming by $\mathrm{CO}_{2}$ (green house gas, GHG) emission caused by global ICT infrastructure.

Based on Islamic resources Qur'an [4] and Sunnah; all the universe created by Allah SWT and all its components and creatures are integrated and run in a consistent, accurate, balanced and perfect way. The human has a leading role in this universe as vicegerent of Allah SWT "Allah the Lord said to the angels: I will create a vicegerent on earth" [Qur'an 2:30]. So human has to follow his Lord rules and regulation to manage the universe and keep life stable and unharmed.

To eliminate environmental problems we have to adopt an efficient strategy for green ICT based on Islamic perspective.

\section{ENVIRONMENTAL PROBLEMS: THE ROLE OF ICT}

In this information era, ICT become the driving force to run almost all aspects of life. ICT plays dual role in term of environmental problems (climate change and global warming). Firstly is the consumption of power by ICT equipment which leads to GHG or $\mathrm{CO}_{2}$ emission, and secondly is using ICT to enhance the efficiency of energy consumption in other sectors (industry, healthcare, education, etc). To understand the ICT role in GHG or $\mathrm{CO}_{2}$ emission; several analyses have been done on the economic impact of ICT equipment on climate change and global warming. It shows that the ICT industry $\mathrm{CO}_{2}$ footprint is about to exceed than the aviation industry [5]. The growth rate of energy consumption and $\mathrm{CO}_{2}$ emissions is doubling about every 5 years [6] and this rate can grow further. On the other hand we also have to know the contribution of ICT applications in reducing $\mathrm{CO}_{2}$ emission produced in other sectors. ICT emissions are relatively little compared to other industries, but we have to know that it is almost the fastest growing sector in terms of usage and $\mathrm{CO}_{2}$ emissions. ICT industry could be one of the larger industry sources of green house gas emissions. It is estimated that ICT industry consumes anywhere from $6-10 \%$ of the world's energy, and about half of these emissions are from personal computers and mobile phones [5]. ICT industry has indirect contribution to $\mathrm{CO} 2$ emission through its consumption of electrical power to run the ICT electronic equipments and keep it cool, since every watt consumed by electronics equipments results in heat, which requires almost equal or greater amount of electricity for cooling ICT equipment [7].

The big question is: did the ICT Technology improvements and better energy efficiency is enough while those savings are lost to greater consumption? [8]. The result shows that the improvements in efficiency have done little to reduce actual energy consumption since consumers take advantage of those gains to have more usage for ICT equipments, drive bigger cars farther, or heat larger homes, etc [9]; this may result in greater $\mathrm{GHG}\left(\mathrm{CO}_{2}\right)$ emissions. As such any strategy for the green ICT infrastructure must undertake a systemic approach and should not assume that individual energy savings of either ICT equipment or processes can necessarily result in overall global reduction in energy or $\mathrm{CO}_{2}$ emissions [3].

Improving efficiency of ICT equipment or ICT processes will lead to increase the energy efficiency directly. But we have to know that the technical solution in enhancing the efficiency of energy consumption is not enough unless it is integrated with enhancing and enriching the educational, cultural and ethical aspects of society to make people feel responsibility. 
The general understanding of ethics in Islam can be express as a "set of moral principles and guidance that recognizes what is right behavior from what is wrong or what one should do or not". Qur'an and Sunnah, show that all the Muslims' life should be guided by Islamic ethics [10-13]. Responsibility is an essential factor in Islamic ethical principles, which is shown in many Qur'anic verses and Prophet Sunnah. Islam specifies the responsibility for every people based on his role in life. Prophet Mohammed (peace and blessings upon him) said "Every Muslim is a shepherd (leader) and he is responsible for that which he shepherds".

Although several countries and organizations have introduced green ICT strategies or polices to address these issues but we still need for more efforts that respected Islamic viewpoint. Such strategy or policies will serve Islamic world as well as others because of the universality, comprehensiveness, stability, and fairness of Islamic principles.

\section{GREEN ICT: ENERGY CONSUMPTION}

Green environment, green life, and Green ICT are sample of the terms that become widely used in the last few years. Green ICT term has defined by several organizations, researches, and authors based on their viewpoint for the concept. Samples of these meaning of Green of ICT are shown in this section. Organization for Economic CoOperation and Development OECD, which have 30 countries as members defined Green ICT as "ICT to reduce environmental load and ICT for using as a promoter to relieve social environment influence" [14]. The Danish Ministry of Science Technology and Innovation defines Green ICT as "more environmentally friendly utilization of IT and the use of sustainable IT" [15]. Ministry of Economy, Trade and Industry in Japan defined it as "Saving in ICT-related energy consumption and energy conservation through the use of ICT" [16]. Gartner defines Green ICT as "Encompassing environmentally sustainable IT and the use of IT to contribute to environment preservation" [17]. Other definition of Green ICT is "reduction of energy consumption and pollution of environment through IT" [18]. Malaysia green ICT working group concept about green ICT is "Refers to conserving energy, using computing resources efficiently, reducing carbon emissions, appropriate handling of hazardous waste" [19]. However, we can add new definition for Green ICT as "The wise usage of ICT to minimize the resources consumption and reduce GHG emission that leads to environment protection and better life".

ICT energy consumption analysis shows that there are mainly five distinguish categories of equipment $[20,21]$ including data centers, PCs, NW equipments, TVs, and others. A summary description of these categories as:

a) Data center equipment, which comprises computing, storage and network equipment in data centers, but additional supporting equipment like heating ventilation and air conditioning and UPS as well.

b) PCs, which comprise both laptops and desktop computers.

c) Network equipment, which include switches, routers, modems and home gateways. Network interface cards are not considered in this category as they are either accounted for in PCs or data centers.

d) TVs, including additional equipment like DVD players.

e) Other devices like telephones, mobile phones, printers, fax machines, etc.

An Australian computer society ACS published a report in 2010 about energy consumption and carbon footprint of ICT usage in Australia [22]. ICT is responsible for nearly 2.7 percent of Australia's total carbon emissions. More significantly, it is directly 
responsible for more than 7 per cent of all electricity generated in Australia. These are significant figures, particularly given that Australia is one of the largest carbon emitters per capita in the world. In 2009 Australia's ICT users consumed 13.248 million kilowatt hours $(\mathrm{kWh})$ of electricity, which caused 14.365 Megatonnes (Mt) of $\mathrm{CO}_{2} \mathrm{e}$ (carbon dioxide equivalent) emissions. Table 1 shows the Energy Consumption and ICT Carbon Footprint in Australia, 2009.

Table 1: Energy Consumption and ICT Carbon Footprint in Australia, 2009 [22].

\begin{tabular}{|l|l|l|l|}
\hline & $\mathbf{K W h} /$ year & $\mathbf{C O}_{2} \mathbf{e}$ & \% of $\mathbf{C O}_{\mathbf{2}} \mathbf{e}$ \\
\hline Total data centre & $4,572,118$ & $4,936,650$ & 34.4 \\
\hline $\begin{array}{l}\text { Total other } \\
\text { enterprise }\end{array}$ & $2,989,078$ & $3,223,620$ & 22.4 \\
\hline Total household & $4,639,737$ & $4,971,743$ & 34.6 \\
\hline NW infrastructure & $1,047,105$ & $1,232,86$ & 8.6 \\
\hline Total & $\mathbf{1 3 , 2 4 8 , 4 1}$ & $\mathbf{1 4 , 3 6 4 , 8 3 2}$ & $\mathbf{1 0 0 . 0 0}$ \\
\hline
\end{tabular}

Based on Pickavet study on worldwide energy needs for ICT [23] an analysis done for the worldwide electricity consumption of the equipment in these five categories for 2008 and their respective growth levels in order to predict a business as usual case for 2020. The analysis compared this with the global energy and electricity consumption levels as summarized in the following Table 2 [24]. Based on that main conclusion are summarized [20] as: the power consumption is fairly equally distributed between the different categories. This means that in order to realize large optimizations in the ICT power consumptions, all these categories need to be tackled. It also implies that when evaluating solutions one should investigate the impact in all these areas. The analysis found that ICT consumes about $7 \%$ of the electricity consumption, which is fair fraction. However, this fraction will be double by 2020 in a business as usual scenario; so we have to find a suitable solution for this problem.

Studies, research work, and discussions shows that; although ICT sector itself has clear contributes the global GHGs emission, but the reduction done in other sectors, which uses ICT applications would be greater. A recent report by Global e-sustainable initiative (GeSI) estimates the use of ICTs can help reduce annual global GHGs emission 15 percent by 2020. The reduction corresponds to 7.8 billion tonnes of $\mathrm{CO}_{2}$ equivalent [25].

Table 2: World ICT Power Consumption [24].

\begin{tabular}{|l|l|l|l|}
\hline Category & $\begin{array}{l}\text { Power consumption } \\
\mathbf{2 0 0 8}(\mathbf{G W})\end{array}$ & $\begin{array}{l}\text { Growth } \\
\text { Rate (p.a.) }\end{array}$ & $\begin{array}{l}\mathbf{2 0 2 0} \text { prediction } \\
(\mathbf{G W})\end{array}$ \\
\hline Data centers & 29 & $12 \%$ & 113 \\
\hline PCs & 30 & $7.5 \%$ & 71 \\
\hline Network Equipment & 25 & $12 \%$ & 97 \\
\hline TVs & 44 & $5 \%$ & 79 \\
\hline Other & 40 & $5 \%$ & 72 \\
\hline Total & $\mathbf{1 6 8}$ & & $\mathbf{4 3 3}$ \\
\hline $\begin{array}{l}\text { Worldwide } \\
\text { Electricity }\end{array}$ & 2350 & $2 \%$ & 2970 \\
\hline
\end{tabular}




\begin{tabular}{|l|l|l|l|}
\hline ICT fraction & $7.15 \%$ & & $14.57 \%$ \\
\hline
\end{tabular}

Governments, organizations, universities, and industries have to pay attention to the role of ICTs in mitigating and adapting climate change, particularly GHGs emission: They need to improve environmental performance of ICT sector as well as improve environmental performance by ICT applications to other sectors [27]. The global green ICT market shows fast growing. While the market is estimated to 0.5 billion dollars in 2008 , it is expected to 4.8 billion dollars in 2013.

\section{THE CONCEPT OF ENVIRONMENT FROM ISLAMIC VIEWPOINT}

Islam is the last religion revealed by Allah (God, Almighty) as evident from the Qur'an [4] "This day, I have perfected your religion for you, completed my favour upon you, and have chosen for you Islam as deen (religion" [Qur'an 5:3]. Islam is basically based on two sources: The Holy Qur'an and the Sunnah of Prophet Mohammed (pbuh). Sunnah is mainly defined by Muslim scholars as: "all what prophet Mohammed (pbuh) says, acts, or agreed on". People have to consider Qur'an as the highest standard that they should follow in their life and work. "Verily this Qur' an jdoth guide to that which is most right (or stable)" [Qur'an 17:9].

The main objective of creating all mankind by God (Allah SWT) is to warship him; by developing and reconstructing the earth for the best (as vicegerent) through their good acting and deeds. Allah SWT said "I have only created Jinn and Human, that they may serve (worship) me” [Qur’an 51:56].

Since the proposed green ICT strategy will be for used in several Islamic countries; so we have to study the Islamic viewpoint on environment based on Quran and Sunnah. Several Islamic authors and organizations have great effort in this topic. ISESCO has several studies one of them is related to environment in Islam. Studies shoes that environmental issues has increased today as skills have developed more quickly than wisdom and rationalism and as environmental problems have become a reality endangering human life both in the present and in the future. The situation could become worse unless human beings change their behavior to the better.

It goes without saying that if human beings had abided by the teachings of Islam, complied with its injunctions, and heeded its warnings, they would have avoided all the causes at the root of environmental problems. Allah, Sublime be His Name, the Creator of the human soul, knows what is good and what is bad for that very soul. Almighty Allah said in His Holy Book: "Should He not know-He that created. And $\mathrm{He}$ is One that understands the finest mysteries (and) is well-acquainted (with them) " [Qur' an 67:14].

Islam has tackled all environmental issues in a comprehensive manner, without going into the finest details. Allah, Most High, said: "Nothing have we omitted from the Book " [Qur'an 6:38]. In another surah, He said: "Then We (Allah SWT) put thee on the (right) way of religion: so follow thou that (way)" [Qur'an 45:18]. Furthermore, in the Hadith, the Prophet has dealt with all of the topics that came up in the Qur'an. Allah said: "Nor does he speak of (his own) Desire. It is only a Revelation revealed.“ [Qur' an 53:3-4].

The ISESCO study on Islam and environment discusses: 
- The deals from an Islamic viewpoint with the concept of environment as both a civilizational and natural reality.

- Highlights the signs of the divine miraculous and inimitable creation of nature.

- Addresses environmental issues and their causes as a result of the interaction of elements from the natural and cultural systems. It also sheds light on the opinion of the Qur' an and the Prophet on these problems. For had human beings abided by their faith and its regulations, they would have spared themselves all of these environmental problems.

Environment is defined as the sphere or context where human beings live. This includes all the natural and human phenomena [28] that affected humans and are affected by them and from which they get their means of subsistence such as food, clothing, medicine and shelter and wherein they exercise their relations with their human and nonhuman fellow creatures [29]. In a prominent environmentalist's view [30]: "The environment is a set of conditions, substances and interactions taking place in any sphere where life exists".

- Conditions include such climate elements as temperature, humidity, and light as well as cosmic states such as gravity.

- Substances comprise the earth and what is related to it like rock constituents, running water in rivers which fills the seas, and such life products as paper, fruits, wood, fur, meat and the like.

- Two kinds of interactions: physical interactions as chemical transformations and vital interactions related to the growth of living organisms.

The scope of interactions can be local including the interaction between individuals and their surroundings. It can also be of wide scope as is the case with water circulation and the movements of wind. Similarly, the sphere may be limited or may expand to include all the vital surroundings i.e. the sphere where life exists, that of the atmosphere, the hydrosphere and the lithosphere. This means that the environment is three-dimensional involving the ecological dimension, the socio-economic dimension, and the socio-cultural dimension (the system of values).

\section{EFFORT FOR GREEN ICT STRATEGY}

The developed countries as well as some of the developing and Muslim countries are increasing the investment in green ICT as a new growing market but we need more contribution from others. We can summarize some of such effort for Green ICT strategy as:

A Korean effort in green ICT strategy is shown in [18]. This study has significance as the base research for Green ICT policy making. It focuses on applying analytical hierarchy process. It considers priorities of primary goals to increase policy efficiency of Green ICT.

Malaysian Green ICT working group established in July 2010 to promote the usage of Green ICT in Malaysia particularly the telecommunication industries [19]. Its main mission is: set up a minimum Green ICT guidelines that can be used across industries; Seeking sustainable ICT industry development through eco-friendly technology; Streamlining the effort of the private sectors and government to ensure Green ICT will become a standard; Currently has more than 40 members and 3 active working threads (till Nov 2010). There concept about green ICT is: 
- Refers to conserving energy, using computing resources efficiently, reducing carbon emissions, appropriate handling of hazardous waste

- Driven by the desire to reduce cost, benefit the environment and be a good corporate citizen

Australian computer society ACS works toward green ICT strategy to help ICT professionals reduce carbon dioxide emissions from ICT equipment by developing a green ICT policy outlining initiatives to reduce the organizations carbon footprint and guidelines on the safe disposal of old technology and leverage innovative technologies to reduce power consumption and lower carbon dioxide emissions [31].

The Royal borough of Kensington and Chelsea, Green ICT Strategy is based on strategic objectives include [32]: Reduce the amount of energy consumed by our ICT equipment; Ensure equipment is turned off when not in use; Reduce paper consumption; Work with the Change Programs to identify the impact of the changes they propose.

\section{FRAMEWORK FOR NEW STRATEGIC GREEN ICT POLICY}

Although there are many attempts and efforts done to enhance the green ICT performance and eliminate the GHG emission as well as adopting set of policies and strategies by several governments and organizations but there are still some weaknesses that we have to work on. This paper proposes a framework for new strategic green ICT policies to eliminate the current environmental problems. This framework are represented in different layers starting from the Ummah layer, state layer, until individual layer then the technical layer to show technically what we have to do to eliminate the harm on environment and get green ICT. These layers include:

a) The Universal (Ummah) Layer: we have to define the main Green ICT strategy and policies to protect environment on international level (Muslim Ummah). This layer include the following steps:

- Define and adopt a unified and standard the high strategy for Green ICT for the whole Ummah.

- Prepare a plan (with alternatives) and time schedule required to implement this strategy and have the mechanism to follow the implementation and adjust plan in emergency or critical cases.

- Having rules and regulations to easiest the implementation of the strategy and to have no conflict with other plans.

- Facilitate the cooperation between different countries to succeed in implementing the strategy

b) The country Layer: we have to define the main Green ICT strategy and policies for each country. This layer include the following steps:

- Define and adopt a unified and standard strategy and policies for Green ICT for the whole country.

- Prepare a plan (with alternatives) and time schedule required to implement the country strategy and policies and have the mechanism to follow the implementation and adjust plan in emergency or critical cases.

- Having rules and regulations to easiest the implementation of the country strategy and policies and to have no conflict with other plans.

- Facilitate implementation of strategic plan and policies by offering the suitable rules and regulations, budget, professional, education and training. 
- Facilitate the cooperation between different ministries and organizations in the country to succeed in implementing the country Green ICT strategy and polices.

- Developed countries should participate in the main effort to solve environmental problems since they are responsible and highly contribute in creating such problem.

c) Education, Research and Training Organizations Layer: we have to define the role of educational institutes, research centers and training organization to understand and implement Green ICT and environment protection strategy and policies.

- Prepare a strategy to educate and train people to understand and implement Green ICT.

- Enrich the university programs, professional and training program with Green ICT concept and implementation to enhance society and human life.

- Prepare set of courses related to Green ICT (problem causes, proposed solutions, implementation and benefits).

- Support research activities in Green ICT and environmental protection.

d) Companies and Production Organizations Layer: we have to define the role of Companies and Production Organizations to understand and implement Green ICT and environment protection strategy and policies. So they have to get all their products in line with Green ICT.

- Prepare a strategy and policies to get high quality and environment friendly (Green ICT) products.

- Prepare an effective and efficient strategy and policies to collect, recycle and reuse of previously sold products.

- Prepare a suitable plans and time schedule for implementing and tracking the above strategy.

- Company strategy should be consistent with the country strategy for Green ICT.

- Prepare training for professional courses related to Green ICT.

- Company have to work based on ethical and moral principles in term of getting green ICT and environment and not consider gaining money is the highest or the only target.

e) NGO, Social and Islamic committees and Organizations Layer: we have to define the great role that the non-governmental organizations, social and Islamic organizations and committees as well as the Masjid (Mosque) can play to explain the importance and warn from harmfulness related to Green ICT.

- NGOs, social and Islamic committees and organizations (including Masjid) have to prepare their strategy of work and prepare plan toward Green ICT and environment.

- They have to importance of green environment and how to protect it.

- Show Islamic viewpoint related to environment and its protection.

- Show the ethical aspects and its role in getting Green ICT and environment.

f) Human or Individual Layer: we have to define the great and key role of human to the success in adopting and implementing the Green ICT strategy and Policies.

- The role of human (as vicegerent of Allah SWT) in this universe.

- The ethical aspect and moral behavior is an essential factor to succeed in Green ICT.

- Education and training to enhance human understanding for environmental problem and his role in having Green ICT and environment.

g) Technical Layer: we have to define the technical aspects that we have to follow and implement it which can lead to Green ICT and environment protection. 
- More enhancement for data centers to get efficient energy consumption for servers, cooling system, and other operation environment.

- Using virtualization technology to reduce number of servers used.

- Disable screen savers and implement sleep mode in the time of inactivity for ICT equipments.

- Using efficient and qualified NW and communication equipments and facilities.

- Using grid computing to replace most of the individual PCs.

- $\quad$ Shutting down all the unused PCs and Laptops after office hours.

- Using timer to turn off the peripherals (printers, scanners, LCDs, screens) automatically when unused for few minutes.

- Using an efficient and high quality equipment and power supply.

- Using default green printing (gray scale).

- Recycle toners cartridges and papers.

h) Developing a mathematical and statistical module to evaluate the performance of Green ICT. We have to specify and measure the factors that lead to environmental problem and its relation to green ICT.

\section{CONCLUSION}

Green ICT and Green environment are the main challenges in the $21^{\text {st }}$ century. ICT became the driving force for the progress and development in all our life aspects. ICT has significant role and participation in climate change and green house gas emission. ICT industry has a tremendous role and contribution to the global economy but on the other side ICT is responsible for $2-3 \%$ of the global carbon footprint. ICT plays another significant role through ICT applications in other sectors by efficient consumption of energy and high performance of sector. Leaders, governments, organizations, universities, research centers, and individuals organize summits, conferences, projects, and other activities work toward less consumption of energy and less harmful. They have to find efficient and effective solutions for better utilization and management for resources, improving environmental performance, eliminate global warming. ICT is an essential part of our life, which have significant effect on environment. The emerging economy and technological advances in developing and Islamic countries as well as China and India will lead to rapidly increase the global access of ICT services, which bring more environmental problems. The highly dependence on ICT in all aspects of life implies facing its harmful affect on environmental and social aspects. So we have to eliminate the global warming by $\mathrm{CO}_{2}$ or green house gas GHG emission caused by global ICT infrastructure.

This paper is a step toward adopting new Green ICT strategy and policies to eliminate environmental harms toward getting green environment. It shows the concept of environment and its protection from Islamic viewpoint. This research work is initial framework and a stone within the solution of global environment destruction. It shows the required steps and guidance in each layer. Following this frame work will lead to have Green ICT and a step towards Green environment.

\section{REFERENCES}

[1] Postnote "ICT and CO2 emissions", December 2008 Number 319

[2] Simon Forge, "Powering down: remedies for unsustainable ICT", foresight, Journal, Volume: 9 Issue: 4, Page: 3 - 21, 2007 
[3] M. Tahir Riaz, José M. Gutiérrez, Jens, M. Pedersen, Strategies for the next generation green ICT infrastructure, $2^{\text {nd }}$ International symposium on applied sciences in biomedical and communication technologies ISABEL, 2010. ieeexplore.ieee.org/iel5/5367316/5373603/05373604.pdf.

[4] The Nobel Qur'an, English Translation of the meaning and commentary, King Fahd complex for printing holy Qur'an, KSA, $1417 \mathrm{H}$.

[5] Rich Lechner, "An Inefficient Truth", Global Action Plan, IBM, August 28, 2008

[6] Phil Mckenna, "Can we stop the internet destroying our planet?", New Scientist, issue 2637, 03 January 2008

[7] Santad, Ijcsns, "Visual Basic Software Tool for FTTH Network Management System" International Journal of Computer Science and Network Security, VOL.9 No.2, February 2009

[8] Jeff Rubin, The Efficiency Paradox, Strategecon, CIBC World Markets, November 27, 2007

[9] Don MacLean, "ICTs, Innovation and the Challenge of Climate Change", International Institute for Sustainable Development Bill St. Arnaud, Chief Research Officer, CANARIE Inc., May 2008

[10] Abu Da'ud Sulayman ibn al-Ash'ath al-Sijistani al-izdi, "Sunan Abi Da'ud", Bayrut : Dar Ibn Hazm, 1997.

[11] Al Bukhari Muhammed Bin Ismail, "Shahih al-Bukhari”, Bayrut : Dar al-Fikr, 1981

[12] Al-Ghazali Muhammad, "Khuluq al-Muslim", Damascus : Dar al-Qalam, 2004.

[13] Al-Ghazali Abu Hamed, "Ihya' 'ulum al-din", Bayrut : Dar al-Ma' arifa, 1900.

[14] OECD, "Toward Green ICT Strategies: Assessing Policies and Programmes on ICT and the Environment", Organization for Economic Co-Operation and Development OECD, 2009. www.oecd.org/dataoecd/47/12/42825130.pdf

[15] Danish Ministry of Science Technology and Innovation(MSTI), "Action Plan for Green IT in Denmark," 2007.

[16] S. H. Park, "Strategy to Promote Low Carbon Green Growth Based on ICT," National Information Society Agency, 2009.

[17] Gartner, "Gartner Identifies The Top 10 Technologies for 2008," 2008

[18] Yong Ho Shim, Ki Youn Kim, Ji Yeon Cho, Jin Kyung Park and Bong Gyou Lee, Strategic Priority of Green ICT Policy in Korea: Applying Analytic Hierarchy Process, World Academy of Science, Engineering and Technology, 58: 2009: www.waset.org/journals/waset/v58/v58-4.pdf

[19] Nur Faezal Elias, ICT going green in Malaysia, Seminar by Malaysian green ICT working group, Nov, 2010.

[20] Willem Vereecken, Ward Van Heddeghem, Didier Colle, Mario Pickavet and Piet Demeester, Overall ICT Footprint and Green Communication Technologies, Proceedings of the 4th International Symposium on Communications, Control and Signal Processing, ISCCSP 2010, LimasBol, cyprus, 3-5 March 2010

[21] Gartner Research, Conceptualizing "Green IT" and data centre power and cooling issues, 2007

[22] Graeme Philipson, The Energy Consumption and Carbon Footprint of ICT Usage in Australia in 2010, Australian Computer Society, 2010.

[23] M. Pickavet, W. Vereecken, S. Demeyer, P. Audenaert, B. Vermeulen, C. Develder, D. Colle, B. Dhoedt, and P. Demeester, "Worldwide energy needs for ict: The rise of poweraware networking," in Advanced Networks and Telecommunication Systems, 2008. ANTS '08. 2nd International Symposium on, Dec. 2008, pp. 1-3.

[24] International Energy Outlook 2009. Energy Information Administration, 2009, ch. Electricity, pp. 63-84

[25] Global e-Sustainability Initiative, SMART 2020:Enabling the Low Carbon Economy in the Information Age, 2008, available at : http://finance.gov.auipublications/ICTReview/index.html 
IIUM Engineering Journal, Vol. 12, No. 5, 2011: Special Issue on Science and Ethics in Engineering

[26] Seungdo Kim1, Hyeon-Kyeong Kim2, Hyoung Jun Kim3, Climate Change and ICTs, International Telecommunications Energy Conference, INTELEC 2009, ieeexplore.ieee.org $>$ Conferences > Telecommunications Energy Conf .

[27] Organization for Economic Co-operation and Development/ Directorate for Science Technology and Industry/Committee for Information, Computer and Communications Policy, Towards Green ICT Strategies, 2009.

[28] Michael Allaby, A Dictionary of Environment, (London: Macmillan , 1981).

[29] Mohammed Sayyid Jamil, Addimoghrafia fittarbiyya Assukkania, (Cairo : Dar Gharib Littiba'a wannashr, 1987) .

[30] Mohamed Abdelafattah Alqassas, Al-'Insa'n wa Qadaya al-Bi'a : Bahth Kitab al-I'la'm alArabi waql-Qada'ya al-Bi'iyya, Cairo : Ma' ahad al-Buhuth waddirasat, 1991.

[31] Australian Computer Society Policy Statement on Green ICT, Aug 2007, www.acs.org.au

[32] The Royal borough of KENSINGTON and CHELSEA, Green ICT Strategy: Efficient, Sustainable, Responsible, December 2008, www.rbkc.gov.uk/environmentandtransport/.../idoc.ashx?docid..a2c4 